\title{
Kształcenie umiejętności efektywnego stuchania na lekcjach języka polskiego
}

\author{
Developing the skill of effective listening \\ in Polish language lessons
}

\author{
Marta Urszula Chyb \\ Uniwersytet Opolski
}

\begin{abstract}
The aim of this article is to verify the way in which authors of school textbooks propose develop listening comprehension in Polish language lessons. The author, after discussing the specifics of listening within an interpersonal communication and detailed perceptual skills, sets objectives of improving the auditory reception in Polish language education. Subsequently, she presents an analysis of didactic tasks that are classified according to a perceptual skill which are being developed. The article finishes with the presentation of a model of developing listening comprehension that emerges from selected school textbooks.
\end{abstract}

Key words: effective listening, perceptual skills, developing, didactic tasks, school textbook, Polish language education.

Streszczenie: Celem niniejszego artykułu jest zweryfikowanie, w jaki sposób autorzy podręczników szkolnych proponują kształcić umiejętność słuchania na lekcjach języka polskiego. Autorka po omówieniu specyfiki słuchania w komunikacji interpersonalnej oraz szczegółowych sprawności percepcyjnych, wyznacza cele doskonalenia słuchowego odbioru w edukacji polonistycznej. Następnie przedstawia analizę zadań dydaktycznych sklasyfikowanych ze względu na rozwijaną sprawność percepcyjną. Artykuł kończy się ukazaniem modelu kształcenia umiejętności słuchania wyłaniającego się z wybranych podręczników szkolnych.

Słowa kluczowe: efektywne słuchanie, sprawności percepcyjne, kształcenie, zadanie dydaktyczne, podręcznik szkolny, edukacja polonistyczna.

Słuchanie jest pierwszą opanowywaną przez dziecko umiejętnością komunikacyjną, stanowiącą podstawę dla pozostałych sprawności: mówienia, czytania i pisania. Percepcja słuchowa to również najczęściej wykorzystywana aktywność w procesie porozumiewania (Adler i in. 2006, 178-179), ale jej efektywność ocenia się jedynie na 25\% (Lipińska 1994, 75). Dzieje się tak, gdyż odbiór słuchowy jest umiejętnością 
skomplikowaną, na którą składają się procesy fizjologiczne i poznawcze. Ponadto efektywność percepcji słuchowej uzależniona jest od czynników zewnętrznych, np. sprzyjającej sytuacji odbioru, kompetencji komunikacyjnej nadawcy, oraz wewnętrznych, m. in. kompetencji językowej słuchającego, jego znajomości języka, praktyki w słuchaniu, pamięci słuchowej, zainteresowania tematem, sprzyjającego stanu psychicznego i fizycznego, braku uprzedzeń w stosunku do nadawcy (Lipińska 1994, 78; Morreale, Spitzberg, Barge 2007, 220-226).

Polska szkoła w 1999 r. postanowiła doskonalić kompetencję komunikacyjną w ramach edukacji polonistycznej. W podstawie programowej zapisano szereg sprawności składających się na umiejętność słuchania, czytania, mówienia i pisania, które należało kształcić na lekcjach języka polskiego. Opublikowano wiele tekstów poruszających problematykę rozwijania i doskonalenia kompetencji komunikacyjnej, w większości skupiały się one jednak na sprawności nadawania komunikatów (ustnych i pisemnych) oraz odbioru tekstu pisanego (czytania ze zrozumieniem). Umiejętności słuchania poświęcono niewiele prac (Patrzałek 1997, 1998; Stróżyński, 2001), w których starano się przybliżyć nauczycielom jej specyfikę i wskazywano w ogólnym zarysie sposoby doskonalenia percepcji słuchowej w ramach edukacji polonistycznej. Mimo że nauczanie komunikacyjne nadal stanowi jedną z głównych koncepcji kształcenia językowego w szkole, a w podstawie programowej z 2008 r. zostały zapisane cele nauczania odnoszące się do czterech umiejętności komunikacyjnych (mówienia, pisania, czytania i słuchania), problem kształcenia sprawności odbioru słuchowego w publikacjach naukowych i metodyczno-przedmiotowych wciąż jest pomijany. W efekcie do tej pory $\mathrm{w}$ języku polskim jako ojczystym nie została wypracowana metodyka kształcenia percepcji słuchowej. Celem niniejszego artykułu jest zweryfikowanie, w jaki sposób, mimo braku rozwiązań metodycznych, autorzy podręczników szkolnych proponują kształcić umiejętność słuchania w ramach edukacji polonistycznej.

\section{Specyfika umiejętności słuchania}

Percepcja dźwięków to proces skomplikowany, wymagający prawidłowego funkcjonowania narządu słuchu. Podstawę słuchania stanowi słyszenie, które polega na odbieraniu, przewodzeniu i przetwarzaniu dźwięków otaczających człowieka (Adler i in. 2006, 181-185; Gronbeck 2011, 56; Morreale, Spitzberg, Barge 2007, 208-209). Jest to proces nieświadomy, automatyczny, stanowi naturalną reakcję organizmu na dźwięki. Z kolei słuchanie to proces poznawczy uruchamiający procesy myślowe. W przeciwieństwie do słyszenia jest czynnością świadomą, wykonywaną aktywnie, ponieważ polega na postrzeganiu i uświadamianiu sobie tego, 
co się słyszy, innymi słowy - człowiek odbiera i identyfikuje jedynie te dźwięki, które są dla niego istotne, zaś pozostałe świadomie ignoruje (Brześkiewicz 1999, 29).

Poza słyszeniem (recepcją dźwięku) ważną rolę odgrywa słuch fonematyczny (mowny). Według Bronisława Rocławskiego jest to zdolność do kwalifikowania wyróżnionych z potoku mowy głosek jako przynależnych do określonych fonologicznie zdeterminowanych głosek (Rocławski 1995, 20). W jego skład wchodzą: słuch fonemowy - odróżnianie/utożsamianie dwóch wypowiedzi różnych lub takich samych fonologicznie; słuch fonetyczny - odróżnianie różnych głosek stanowiących tę samą klasę głosek (fonem); słuch prozodyczny - różnicowanie elementów prozodycznych wypowiedzi, np. akcentu, melodii, rymu; analiza i synteza głoskowa/sylabowa - umiejętność świadomego wyróżniania głosek/sylab w wypowiedzi (z zachowaniem ich kolejności) i łączenia głosek/sylab w całość brzmieniową (Kurkowski 1997, 105).

Odbiór wypowiedzi rozpoczyna się od percepcji pojedynczych dźwięków, ich rozróżniania i rozpoznawania, a dopiero w drugiej kolejności dochodzi do asocjacji dźwięków mowy, czyli kojarzenia słuchowych wzorców z odpowiednimi pojęciami i przypisania znaczeń usłyszanym wypowiedziom (Kurkowski 1997, 105). Jest to proces naturalny, automatyczny i w przypadku braku jakichkolwiek zaburzeń przeważnie nie wymaga doskonalenia. Niemniej jednak, szczególnie w pracy z młodszymi dziećmi, kładzie się nacisk na rozwijanie zdolności różnicowania dźwięków i ich dekodowania (zmiany głosek na litery i odwrotnie), gdyż stanowi to podstawę świadomości językowej, a jej nabywanie bez wcześniejszego usprawnienia analizy i syntezy słuchowej jest znacznie utrudnione (Przybyla 2012, 302). Ponadto, praca nad słuchem fonematycznym wpływa na jakość mówienia, czytania i pisania.

Umiejętność słuchania tekstu mówionego jest procesem bardziej skomplikowanym niż zdolność słyszenia i potrzebuje treningu na wielu płaszczyznach. Z perspektywy poznawczej słuchowy odbiór wypowiedzi składa się z pięciu równolegle przebiegających etapów: świadomego odbioru dźwięków mowy (selekcji informacji), zrozumienia przekazu, jego oceny, zapamiętania, a także reagowania na przetworzone informacje (Morreale, Spitzberg, Barge 2007, 209-210; Adler i in. 2006, 185-188). Aby proces słuchania przebiegł pomyślnie, odbiorca musi aktywnie uczestniczyć w procesie odbioru wypowiedzi. W pierwszej kolejności nastawia się i zwraca uwagę na te komunikaty, które, według niego, są ważne. Następnie informacjom przekazywanym przez nadawcę przypisuje znaczenia, interpretuje je i ocenia ze względu na wybrane kryteria, np. zgodność z prawdą czy z własnym światopoglądem. Kolejnym etapem jest zapamiętanie wybranych i zrozumianych 
informacji. Z kolei ostatnia faza słuchania to reagowanie - odbiorca przekazuje nadawcy komunikat, że jego wypowiedź została odebrana, zrozumiana i zapamiętana.

Wydaje się, że wymienione etapy słuchania są jednocześnie sprawnościami, które powinny być doskonalone na lekcjach języka polskiego. Uczniowie, po pierwsze, muszą być świadomi, które wiadomości są dla nich ważne (co uzależnione jest od celu słuchania), po drugie, powinni je zrozumieć (zgodnie z intencją nadawcy), po trzecie, ocenić (wyrazić opinię na ich temat), następnie - zapamiętać oraz przekazać nadawcy informację, że został wysłuchany. Opanowanie tych sprawności warunkuje zostanie kompetentnym słuchaczem.

Uznaje się, że kompetentny słuchacz to osoba, która posiada motywację do efektywnego słuchania (chce efektywnie słuchać w różnych sytuacjach); ma odpowiednią wiedzę i jest wyposażona w przydatne umiejętności, dzięki którym wie, co ma zrobić, aby efektywnie słuchać; wykazuje zdolność do efektywnego słuchania w różnych sytuacjach komunikacyjnych (Morreale, Spitzberg, Barge 2007, 211). Według badaczy, dla modelu kompetentnego słuchacza najistotniejsze są dwa czynniki, tj. motywacja i umiejętność efektywnego słuchania w różnych sytuacjach komunikacyjnych, ponieważ odróżniają one słuchacza kompetentnego od umiejętnego (Morreale, Spitzberg, Barge 2007, 211). Umiejętny słuchacz jedynie rozumie, na czym polega proces słuchania i jest wyposażony we właściwe narzędzia pozwalające mu efektywnie słuchać. Natomiast kompetentny słuchacz odznacza się ponadto motywacją i umiejętnością słuchania we wszystkich sytuacjach komunikacyjnych, nawet $\mathrm{w}$ takich, które nie są dla niego sprzyjające. Potrafi również zdecydować, kiedy słuchanie jest konieczne, a kiedy nie (Morreale, Spitzberg, Barge 2007, 211).

\section{Umiejętność słuchania w edukacji polonistycznej}

Kompetentny słuchacz w akcie odbioru tekstu mówionego wykorzystuje swoją motywację, wiedzę i umiejętności na wszystkich etapach słuchania (Morreale, Spitzberg, Barge 2007, 226), tj. świadomego odbioru, rozumienia przekazu, jego oceny, zapamiętania oraz reagowania na usłyszany komunikat. Kształcenie umiejętności słuchania na lekcjach języka polskiego można więc przedstawić w formie następujących celów nauczania: 
Tabela 1. Cele kształcenia umiejętności słuchania na lekcjach języka polskiego

\begin{tabular}{|c|c|c|c|}
\hline \multicolumn{4}{|c|}{ Uczeń: } \\
\hline & Motywacja & Wiedza & Umiejętności \\
\hline 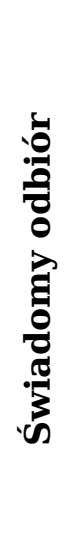 & $\begin{array}{l}\text { - chce } \\
\text { odbierać } \\
\text { komunikaty; }\end{array}$ & $\begin{array}{l}\text { • rozumie, na czym polega } \\
\text { proces słuchania; } \\
\text { • zna czynniki utrudnia- } \\
\text { jące odbiór tekstu; } \\
\text { • wybiera cel słuchania; } \\
\text { • wie, które informacje są } \\
\text { najważniejsze i dlaczego; }\end{array}$ & $\begin{array}{l}\text { - przygotowuje się } \\
\text { do słuchania; } \\
\text { - eliminuje przeszkody, } \\
\text { (np. zmniejsza dystans } \\
\text { między nadawcą); } \\
\text { - skupia uwagę na komu- } \\
\text { nikatach nadawcy; } \\
\text { - wybiera istotne infor- } \\
\text { macje z słuchanych } \\
\text { wypowiedzi; }\end{array}$ \\
\hline 串 & $\begin{array}{l}\text { - pragnie } \\
\text { zrozumieć } \\
\text { komunikat; }\end{array}$ & $\begin{array}{l}\text { • posiada wiedzę i } \\
\text { doświadczenie, warunku- } \\
\text { jące zrozumienie tekstu; } \\
\text { • wie, że zrozumienie tek- } \\
\text { stu zależne jest od wielu } \\
\text { czynników (m.in. kontek- } \\
\text { stu, nadawcy i odbiorcy); }\end{array}$ & $\begin{array}{l}\text { - rozumie odebrane komu- } \\
\text { nikaty (werbalne } \\
\text { i niewerbalne); }\end{array}$ \\
\hline đ̊ & $\begin{array}{l}\text { - chce ocenić } \\
\text { oraz zweryfi- } \\
\text { kować infor- } \\
\text { macje prze- } \\
\text { kazane przez } \\
\text { nadawcę; }\end{array}$ & $\begin{array}{l}\text { • posiada wiedzę pozwa- } \\
\text { lającą na krytyczną ocenę } \\
\text { komunikatu; }\end{array}$ & $\begin{array}{l}\text { - ocenia i weryfikuje usły- } \\
\text { szane informacje; }\end{array}$ \\
\hline 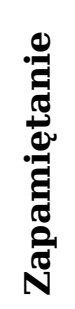 & $\begin{array}{l}\text { - chce } \\
\text { zapamiętać } \\
\text { komunikat; }\end{array}$ & $\begin{array}{l}\text { • zna sposoby ułatwiające } \\
\text { zapamiętanie komunikatu; }\end{array}$ & $\begin{array}{l}\text { - zapamiętuje wybrane } \\
\text { informacje; }\end{array}$ \\
\hline 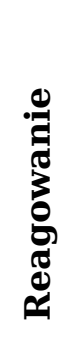 & $\begin{array}{l}\text { - pragnie } \\
\text { przekazać } \\
\text { komunikat } \\
\text { zwrotny. }\end{array}$ & $\begin{array}{l}\text { - rozumie, jakie znaczenie } \\
\text { dla komunikacji ma komu- } \\
\text { nikat zwrotny; } \\
\text { • zna rodzaje komunika- } \\
\text { tów zwrotnych, ich funkcje } \\
\text { i efekty komunikacyjne. }\end{array}$ & $\begin{array}{l}\text { • umiejętnie reaguje } \\
\text { na usłyszane komunikaty. }\end{array}$ \\
\hline
\end{tabular}

Źródło: opracowanie własne. 
Nauczyciele doskonaląc umiejętność słuchania, powinni kształcić wszystkie szczegółowe sprawności składające się na percepcję słuchową, przekazywać wiedzę metakomunikacyjną (o specyfice słuchania, obowiązkach słuchacza w przestrzeni komunikacyjnej itp.) oraz motywować do świadomego odbioru słuchowego różnego rodzaju tekstów. Działania te pozwolą przygotować uczniów do kompetentnej percepcji słuchowej w sytuacjach pozaszkolnych.

Po omówieniu specyfiki słuchania oraz celów kształcenia percepcji słuchowej na lekcjach języka polskiego, warto zastanowić się, w jaki sposób autorzy podręczników szkolnych proponują rozwijać szczegółowe sprawności składające się na efektywne słuchanie. $\mathrm{W}$ tym celu analizie poddałam dziewięć serii podręczników najczęściej wykorzystywanych w opolskich szkołach, po trzy na każdy etap edukacyjny ${ }^{1}$. Wyodrębnione zadania ${ }^{2}$, na potrzeby niniejszego artykułu, podzieliłam ze względu na rozwijaną sprawność percepcyjną. W dużej mierze kategoryzacja ta jest umowna, gdyż podczas odbioru słuchowego słuchacz uruchamia wszystkie sprawności percepcyjne. Jednak analiza wybranych podręczników szkolnych wykazała, że autorzy zadań dydaktycznych często wyróżniają jedną sprawność, którą uczeń będzie doskonalić, wykonując czynności wskazane w poleceniu.

\section{Kształcenie świadomego odbioru komunikatów ustnych}

$\mathrm{Na}$ pierwszą wyodrębnioną umiejętność percepcyjną, tj. świadomy odbiór komunikatu, składają się zarówno wiedza o słuchaniu (metakomunikacyjna), jak i umiejętność selekcji informacji. Analiza wybranych podręczników szkolnych wykazała, że autorzy zadań dydaktycznych zwracają uwagę przede wszystkim na doskonalenie sprawności wyboru istotnych, dla odbiorcy, informacji z komunikatu ustnego.

Sprawność selekcji informacji doskonali się podczas pracy nad umiejętnością notowania ze słuchu. Uczniowie mają za zadanie wyodrębnić z materiału językowego informacje, które zostały wskazane w treści zadania lub samodzielnie wybrać wiadomości niezbędne do wykonania ćwiczenia:

Podczas słuchania utworu pt. „Szczęśliwy książę” wynotuj informacje dotyczące miejsc, w których rozgrywają się zdarzenia, i bohaterów w nich uczestniczących (MN5, 275).

Przygotujcie krótką wypowiedź osoby, która poinstruuje turystów. W tym celu: wysłuchajcie na naszej stronie internetowej fragmentów wypowiedzi dotyczących bezpieczeństwa na szlaku, wykorzystajcie wybrane słownictwo z ramki (MN5, 103).

\footnotetext{
Do analizy wybrałam dziewięć serii podręczników: Między nami, Słowa na start, Teraz polski (II etap edukacyjny), Słowa na czasie, Świat w słowach i obrazach, Między nami (III) oraz Język polski (seria Odkrywamy na nowo), Ponad słowami, Przeszłość to dziś (IV). W niniejszym artykule cytuję jedynie wybrane podręczniki. Rozwinięcia zastosowanych skrótów znajdują się na końcu pracy, zob. Wykaz cytowanych podręczników.

Zadanie dydaktyczne rozumiem jako narzędzie służące nauczycielowi do sterowania procesem przyswajania wiedzy i opanowywania umiejętności przez uczniów (Nocoń 1997, 43). Do analizy wybrałam te polecenia, w których występował operator słuchać albo zwrot przeczytaj na głos (z treści ćwiczenia musiało wynikać, że uczeń będzie obserwował wytwarzane przez siebie dźwięki). Zwróciłam również uwagę na zadania, które mimo że nie zawierały tych operatorów, nakłaniały do odbioru tekstów audiowizualnych bądź audialnych - $\mathrm{np}$. w podręczniku za pomocą symbolu umieszczanego obok polecenia oznaczano konieczność wysłuchania tekstu.
} 
Efektem zadań ma być sporządzona notatka bądź wypowiedź ustna/ pisemna, w których usłyszane informacje zostaną twórczo wykorzystane. Jednak materiałem w większości ćwiczeń jest tekst literacki, więc doskonalenie słuchowego odbioru jest funkcjonalnie ograniczone.

Umiejętność percepcji słuchowej uwarunkowana jest m. in. wiedzą metakomunikacyjną. W analizowanych podręcznikach znajduje się tylko jedno polecenie zapoznające uczniów ze specyfiką słuchania, przypominające zadanie zaproponowane w latach 90. przez Tadeusza Patrzałka, nazwane unaocznieniem skutków złego słuchania (Patrzałek 1997, 369):

\footnotetext{
Przeprowadźcie w klasie następujące ćwiczenie: dwie osoby występują na środek i prowadzą rozmowę. Jedna z wielkim zaangażowaniem opowiada o czymś, co bardzo ją poruszyło. Druga demonstracyjnie okazuje swoje znudzenie. Potem na środek wychodzi druga para. Tym razem osoba słuchająca jest bardzo zainteresowana tym, czego słucha. Po skończonym ćwiczeniu porozmawiajcie w klasie o odczuciach osób mówiących. Na tej podstawie sporządźcie listę wskazówek (co najmniej 5) dla dobrego słuchacza. Użyjcie przynajmniej 3 imiesłowowych równoważników zdania (GiS2, 92).
}

Ćwiczenie to, przeznaczone dla uczniów szkoły gimnazjalnej, inicjuje „naturalną” sytuację komunikacyjną. Uczestnicy zajęć wchodzą w rolę nadawcy i odbiorcy wypowiedzi, a następnie wyrażają swoje odczucia, jakie zostały wywołane przez zachowanie słuchacza. Efektem zadania mają być rady dla kompetentnego odbiorcy tekstów mówionych, wykorzystujące imiesłowowy równoważnik zdania. Można uznać, że jest to ważne ćwiczenie ze względu na uświadomienie, jak ważne w komunikacji interpersonalnej staje się poszanowanie rozmówcy oraz jakimi cechami powinien charakteryzować się kompetentny słuchacz.

Oprócz przytoczonego polecenia w analizowanych podręcznikach nie występują ćwiczenia pozwalające zapoznać uczniów ze specyfiką i istotą procesu słuchania, jego celami, trudnościami oraz sprawnościami składającymi się na słuchową percepcję tekstów. Wydaje się, że tego rodzaju ćwiczenia powinny być częściej organizowane w edukacji polonistycznej, szczególnie na wyższych etapach edukacyjnych, gdzie świadomość przebiegu słuchowego odbioru wypowiedzi i jego osobliwości najprawdopodobniej przyczyniłaby się do przywiązywania większej wagi do percepcji słuchowej w sytuacjach pozaszkolnych, a co za tym idzie - do efektywnego, aktywnego słuchania drugiego człowieka.

\section{Kształcenie rozumienia słuchanych tekstów}

Rozumienie tekstów audialnych i audiowizualnych jest najczęściej rozwijaną sprawnością percepcyjną. Analiza podręczników szkolnych wykazała, że doskonalenie rozumienia tekstów mówionych utożsamia się przede wszystkim z pracą nad sprawnością odbioru wypowiedzi na poziomie lokalnym, z rozwojem umiejętności analizy wyodrębnionych informacji i ich interpretacji. 
Na II etapie edukacyjnym umiejętność lokalnego odbioru wypowiedzi rozwija się wyłącznie podczas słuchania utworów literackich: uczniowie mają wysłuchać tekstu i scharakteryzować wskazaną w instrukcji (poleceniu) postać, np.:

Porozmawiajcie na temat tego, jakimi umiejętnościami wykazał się Tomek podczas malowania płotu. O jakich jego cechach to świadczy? (MN4, 245).

Natomiast podręczniki przeznaczone dla szkoły ponadgimnazjalnej przeważnie stawiają w centrum uwagi film (rzadziej spektakl), np.:

Zastanów się nad postacią cenzora Rabkiewicza (Janusz Gajos) i sytuacją, w jakiej znalazła się ta postać. Co spowodowało przemianę Rabkiewicza? (PtD3, 136).

Dzięki zadaniom tego typu słuchany tekst lub oglądany film na lekcjach języka polskiego jest dokładnie analizowany i interpretowany. Uczniowie są nakłaniani do scharakteryzowania bohaterów, określania motywacji ich wyborów życiowych oraz interpretacji wypowiadanych kwestii. Odbiór materiału dźwiękowego nie jest ukierunkowany (uczniowie zapoznają się z poleceniem tuż po jego percepcji).

Pozostałe zadania nakłaniają uczniów do omówienia relacji pomiędzy tekstem audiowizualnym a utworem literackim, np.:

Obejrzyjcie fragment filmu Katyń Andrzeja Wajdy (89-90 min.). Wyjaśnij, w jaki sposób nawiązuje do tragedii Sofoklesa?(MN3, 43).

Adresaci ćwiczeń mają za zadanie porównać dwa teksty kultury, $\mathrm{m}$. in. omówić podobieństwa i różnice $\mathrm{w}$ kreacji bohaterów lub treści utworów. Podobnie jak w przypadku poprzednich ćwiczeń, percepcja słuchowa/ wzrokowa nie jest ukierunkowana.

Doskonalenie rozumienia tekstów mówionych odbywa się również podczas pracy nad odbiorem wypowiedzi na poziomie globalnym. Najliczniejszą grupę stanowią zadania nakłaniające uczniów do podzielenia się swoimi wrażeniami, skojarzeniami, pierwszymi myślami, jakie zostały wywołane przez słuchowy odbiór, co w praktyce najczęściej sprowadza się do określenia nastroju utworów literackich, np.:

Wysłuchaj recytacji wiersza w wykonaniu nauczyciela. Następnie powiedz, jakie uczucia towarzyszyły Ci w trakcie słuchania? (SnS4, 104).

Zadania te realizują estetyczny wymiar edukacji polonistycznej w szkole, polegający na bezpośrednim kontakcie z literaturą i jej przeżywaniu, czego zaletą jest umożliwienie odbiorcom wyrażenia własnych uczuć w sposób nieskrępowany (Uryga 1996, 28). Pomimo że polecenia dotyczące tzw. wstępnego rozpoznania skupiają się na estetycznych wrażeniach płynących z percepcji słuchowej, wydaje się, że stanowią przygotowanie do doskonalenia rozumienia tekstów: na początku wybrane utwory są przybliżane uczniom, a dopiero w drugiej kolejności analizowane i interpretowane, 
co wiąże się, jak twierdzi Zenon Uryga, z pośrednim kontaktem z tekstem literackim, relacjonująco-sprawozdawczym i opisowo-analitycznym (Uryga 1996, 28).

Pracę nad rozumieniem tekstów na poziomie globalnym utożsamia się także z doskonaleniem sprawności identyfikacji gatunku tekstu, określenia jego głównej myśli, intencji nadawcy oraz relacji nadawczo-odbiorczych, np.:

Wysłuchaj kilku współczesnych ballad, np. autorstwa Leonarda Cohena w wykonaniu Macieja Zembatego. Jaka jest tematyka tych utworów? (SnCz2, 74).

Wysłuchajcie rozmów zamieszczonych na stronie internetowej. Następnie ustalcie, które z nich są rozmowami znajomych (MN4, 9).

Polecenia tego typu wykorzystują zróżnicowany materiał dźwiękowy: tekst literacki, utwór muzyczny bądź rozmowę. Nakłaniają uczniów do wydobycia głównego sensu, przewodniej myśli słuchanych tekstów bądź określenia kontekstu sytuacyjnego wypowiedzi.

\section{Kształcenie umiejętności oceny słuchanych tekstów}

Najbardziej zaawansowaną umiejętnością percepcyjną jest ocena wysłuchanego komunikatu. Analiza wybranych podręczników szkolnych wykazała, że umiejętność tę kształci się na wszystkich etapach edukacyjnych. Najczęściej adresaci ćwiczeń nakłaniani są do oceny głosowych interpretacji utworów literackich, np.:

Wysłuchaj nagrania recytacji wiersza. Następnie odpowiedz na pytania. Czy podobał Ci się sposób odczytania utworu? Wyjaśnij dlaczego. Jakie emocje starał się oddać recytator? (SnS6, 132).

Materiałem językowym jest nagranie recytacji bądź też deklamacja ucznia lub nauczyciela. Uczniowie są zobowiązani do wyodrębnienia z usłyszanych komunikatów wybranych przez siebie aspektów wypowiedzi i ich oceny. Ponadto efekt końcowy ćwiczenia odwołuje się do zrozumienia tekstu, gdyż jego odbiorcy mają za zadanie zdecydować, czy recytator za pomocą głosu oddał treść utworu, jego nastrój, emocje podmiotu lirycznego itp. Często formą doskonalenia słuchania oceniającego jest organizowanie konkursu recytatorskiego, co pozwala doskonalić sprawność koncentracji na słuchanym tekście oraz nakłania do funkcjonalnego wykorzystania wiedzy z zakresu fonetyki i fonologii suprasegmentalnej.

Autorzy zadań dydaktycznych proponują, aby sprawność oceny tekstów doskonalić również podczas pracy nad wyrażeniem opinii na temat tekstu audiowizualnego, najczęściej w formie recenzji, lub utworu muzycznego, np.:

Napisz recenzję, w której ocenisz następujące elementy filmu: scenografię, kostiumy, muzykę, zdjęcia, montaż, reżyserię, grę aktorów, efekty specjalne (PS1.1, 61). 
Wysłuchaj nagrania utworu Pieśń o żołnierzach z Westerplatte w wykonaniu zespołu Forteca. Czy podoba Ci się taka interpretacja wiersza? Uzasadnij swoją odpowiedź (SnS6, 16).

Doskonalenie umiejętności słuchania oceniającego odbywa się wraz z kształceniem kompetencji tekstotwórczej. Efekt słuchania stanowi wypowiedź argumentacyjna pisemna bądź ustna, w której uczniowie wyrażą opinię na temat narracji, dialogów, ścieżki dźwiękowej w filmie lub wykonania głosowego, muzyki utworu (oraz ocenią relacje pomiędzy obiema warstwami nagrania, tj. werbalną i dźwiękową).

Sprawność oceny komunikatów doskonali się także w ramach wyrażenia opinii na temat własnej pracy bądź kolegów/koleżanek z klasy, której wynikiem jest stworzone słuchowisko radiowe, odpowiedź ustna, wygłoszona wypowiedź argumentacyjna lub przeprowadzony wywiad, np.:

Nagraj swoje odpowiedzi na podane pytania. Następnie odsłuchaj nagranie i oceń, czy podajesz rozwiązania adekwatne do poruszonych kwestii, czy mówisz płynnie i używasz starannej polszczyzny (PS2.1, 188).

Wykorzystując zdobyte umiejętności i wiedzę, przeprowadź wywiad z dorosłą osobą na jeden z podanych tematów: współczesna młodzież, sukces, miłość. Treść rozmowy możesz zapisać lub nagrać. Odczytajcie prace w klasie i oceńcie według tabeli podanej w ćwiczeniu 8. Najlepsze możecie umieścić w gazetce szkolnej (GiS3, 174).

Efektem zadań ma być ocena wysłuchanych wypowiedzi ze względu na kryterium poprawności językowej (w tym fonetycznej) i atrakcyjności. Podobnie jak w przypadku poprzednio omówionych poleceń, ewaluacja dotyczy zarówno warstwy dźwiękowej, jak i treściowej tekstu. Większość poleceń wymaga, aby czynności (zakładane rezultaty) zapisane w instrukcji były wykonywane tuż po wysłuchaniu tekstów, więc percepcja słuchowa nie jest ukierunkowana, a zainicjowana sytuacja odbioru pozwala nauczycielom zweryfikować większość sprawności składających się na efektywną percepcję słuchową, tj. świadomy odbiór, rozumienie i ocenę komunikatu.

Doskonaląc umiejętność oceny tekstów audialnych/audiowizualnych, zwraca się również uwagę na rozwój umiejętności słuchania krytycznego, polegającego na poddawaniu ocenie wszystkiego, co zostało usłyszane. Autorzy podręczników proponują, aby umiejętność tę kształcić na III i IV etapie edukacyjnym poprzez analizę reklamy telewizyjnej/radiowej, wywiadu radiowego lub telewizyjnego, debaty/dyskusji medialnej i serwisów informacyjnych, np.:

Obejrzyj w telewizji debatę lub dyskusję z udziałem polityków. Który z uczestników lepiej - Twoim zdaniem - przekonywał do swoich racji i jakimi środkami się posłużył, aby ten cel osiągnąć (PS1.1, 54).

Posłuchaj jednego dnia kilku radiowych i telewizyjnych serwisów informacyjnych. Zanotuj wiadomości, które powtarzają się w obu mediach. Jak o wybranym wydarzeniu mówi się w radiu, a jak - w telewizji? (SnCz3.1, 122). 
Percepcja słuchowa nastawiona jest na analizę warstwy językowej i pozajęzykowej tekstów, co wiąże się z rozpoznawaniem środków perswazji i manipulacji, pytań podchwytliwych, odpowiedzi unikowych itp. Adresaci ćwiczeń zobligowani są do skupienia się na odtwarzanych nagraniach, wyodrębnienia z nich kluczowych - zaznaczonych w instrukcji - elementów, ich zrozumienia i oceny ze względu na kryterium skuteczności i etyczności. Pożądanym efektem zadań dydaktycznych jest odpowiedź ustna przyjmująca charakter wypowiedzi krytycznej. Wydaje się, że umiejętność krytycznej oceny komunikatów ustnych jest jedną z najtrudniejszych sprawności percepcyjnych, a jej opanowanie pozwala świadomie funkcjonować w życiu społeczno-kulturowym.

\section{Kształcenie zapamiętywania usłyszanych informacji}

W analizowanych podręcznikach szkolnych znajdują się ćwiczenia, które nakłaniają do odtworzenia treści wysłuchanych tekstów, co w praktyce sprowadza się do zapamiętania wskazanych w instrukcji informacji. Ponadto służą doskonaleniu rozumienia dosłownego słuchanych tekstów, stanowią przygotowanie do ich interpretacji.

Do kształcenia zapamiętywania wypowiedzi najczęściej wykorzystuje się zadania, których celem jest identyfikacja elementów świata przedstawionego $\mathrm{w}$ utworach literackich. Zadania tego typu przypominają ćwiczenia wykorzystywane do doskonalenia percepcji słuchowej na lekcjach języków obcych. Autorzy podręczników proponują, aby sprawność ta była rozwijana przez:

- zaznaczenie prawidłowych odpowiedzi, np.:

Wysłuchaj wzorcowego odczytania opowiadania w wykonaniu nauczyciela. Bez zaglądania do tekstu wskaż właściwe odpowiedzi. Sprawdź, czy na wszystkie udało Ci się odpowiedzieć poprawnie.

1. Kiedy Muminek znalazł smoka?

2. Gdzie Muminek włożył małego smoka?
A. W poniedziałek.
A. Do wiadra.
B. W środę.
B. Do słoika.
C. W czwartek.
C. Do imbryka.
D. Nie wiadomo.
D. Do pudełka. (SnS4, 145).

- sformułowanie odpowiedzi na postawione pytania lub uzupełnienie tekstu/schematu, np.:

Przedstawcie szczęśliwego księcia. W tym celu wykonajcie zadania. Wysłuchajcie ponownie baśni. W trakcie słuchania uzupełnijcie schemat odpowiednimi informacjami: Kim jest? Gdzie przebywa? Jak spędza czas? Co jest dla niego ważne? Co mówią o nim inni? (MN5, 275).

- rozpoznanie treści szczegółowych tekstu na materiale obrazkowym, np.:

W trakcie czytania przez nauczyciela legendy uważnie przyglądaj się planszy i znajdź na niej te elementy, o których mowa w opowieści (MN4, 262). 
Tego rodzaju ćwiczenia przeznaczone są jedynie dla uczniów szkoły podstawowej. Materiału dźwiękowego dostarczają nagrania, nauczyciel bądź też jeden uczeń odczytujący zamieszczony w podręczniku fragment utworu literackiego.

Doskonaleniu zapamiętywania tekstu służą także ćwiczenia, które nakłaniają do odtworzenia jego treści:

Poproś koleżankę lub kolegę z klasy o wysłuchanie Twojej prezentacji, a następnie jej streszczenie własnymi słowami (PS1.1, 124).

Umiejętność tę rozwija się na wszystkich etapach edukacyjnych. Wydaje się, że jest to zmotywowane potrzebą nauczenia uczniów koncentracji na ustnym materiałem językowym, jego zapamiętaniem i sparafrazowaniem. Ćwiczenia zawarte w podręcznikach wykorzystują zróżnicowany materiał językowy, tj. tekst literacki, audiowizualny i uczniowską wypowiedź argumentacyjną.

Sprawność w zapamiętywaniu informacji ćwiczy się również podczas doskonalenia umiejętności wyodrębnienia słów kluczy z słuchanego utworu lirycznego:

Wysłuchajcie kilkakrotnie utworu Joanny Kulmowej, a następnie zapiszcie te wyrazy, które zapamiętaliście. Przeczytajcie tekst i sprawdźcie, czy zapisane przez was wyrazy pojawiają się w utworze. Sporządźcie listę tylko tych wyrazów i ich form, które są w tekście. Podkreślcie wśród nich te, które - waszym zdaniem - są najważniejsze dla zrozumienia sensu utworu. Ustalcie, które z nich zostały w wierszu użyte w znaczeniu przenośnym (MN6, 193).

Tego rodzaju zadania pozwalają skoncentrować się na słuchanym materiale językowym i wymagają wskazania tych wyrazów, które składają się na sens utworu - charakteryzują jego treść (Bartmiński, Niebrzegowska-Bartmińska 2009, 294). Po wysłuchaniu interpretacji głosowej utworów lirycznych, najprawdopodobniej w wykonaniu nauczyciela, i odtworzeniu zapamiętanych słów, uczniowie nakłaniani są do weryfikacji swoich spostrzeżeń: odnalezienia wybranych wyrazów, zdefiniowania ich, co przyczynia się do zrozumienia głównej myśli odsłuchanych tekstów. Zapamiętanie wskazanych w instrukcji elementów stanowi więc etap przygotowawczy do pracy z utworem poetyckim, jego analizy i interpretacji.

\section{Kształcenie sprawności nadawania komunikatów zwrotnych}

W ramach kształcenia percepcji słuchowej na lekcjach języka polskiego, oprócz pracy nad selekcją informacji, ich rozumieniem, oceną i zapamiętaniem, uczeń powinien mieć możliwość doskonalenia sprawności reagowania na komunikaty mówione. Umiejętność ta w komunikacji interpersonalnej stanowi ostatni etap odbioru wypowiedzi i świadczy o efektywnym słuchaniu odbiorcy. Jednak w analizowanych podręcznikach nie występują zadania pozwalające doskonalić sprawność nadawania komunikatu zwrotnego. Jedynie odautorskie „wiadomości” umieszczane pod/nad zadaniami 
rozwijającymi umiejętność uczestniczenia w dyskusji pozwalają stwierdzić, z jakimi rodzajami reakcji uczniowie są zapoznawani, np.:

Śledź uważnie głosy padające w dyskusji (możesz je skrótowo notować). Jeśli nawiązujesz do wypowiedzi jednego z przedmówców, przypomnij krótko jego stanowisko, np. x jest zdania, że...; x twierdzi, że...; z tego, co mówi x, wynika, że...; jeśli dobrze rozumiem $x-a$, to... (ŚwSiO2, 252).

Ponadto w jednym podręczniku można odnaleźć zadanie zapoznające uczniów ze sformułowaniami, których można użyć do oceny usłyszanej wypowiedzi. Adresaci ćwiczeń nakłaniani są do przypisania dołączonych przez autorów fragmentów wypowiedzi do ich efektu komunikacyjnego:

Wybierz te spośród sformułowań, których możesz użyć w dyskusji, gdy popierasz czyjeś zdanie lub kiedy się komuś sprzeciwiasz. Następnie uzupełnij tabelę.

Nie znasz się na tym; Podzielam twoja opinię; Chyba w ogóle tego nie rozumiesz; Nie o to chodzi; Inaczej się na to zapatruję; Podzielam poglad; Jest mało prawdopodobne, $\dot{z} e . .$. (TP6, 148).

Tylko w czterech podręcznikach można odnaleźć komunikaty/zadanie dydaktyczne, w których zwraca się uwagę na potrzebę reagowania na wypowiedzi przedmówców, co utożsamia się z parafrazą i oceną usłyszanej opinii. Natomiast żadne polecenia nie nakłaniają do nadawania pozostałych komunikatów zwrotnych, np.: zadawania pytań, wyrażania empatii, wspierania nadawcy, analizowania i interpretowania jego wypowiedzi, udzielania rad (Adler i in. 2006, 189), reakcji niewerbalnych, np. utrzymywania kontaktu wzrokowego.

\section{Jak doskonali się umiejętność słuchania na lekcjach języka polskiego?}

Przeprowadzone badania wykazały, że w analizowanych podręcznikach szkolnych najwięcej wagi przypisuje się doskonaleniu sprawności rozumienia ze słuchu, analizy i interpretacji tekstów mówionych, audialnych i audiowizualnych (wyodrębniono 100 tego rodzaju poleceń) oraz ich oceny (60). Stosunkowo często pracuje się również nad zapamiętywaniem treści usłyszanej wypowiedzi (34). Pozostałe sprawności percepcyjne są marginalizowane: najmniej uwagi poświęca się doskonaleniu świadomego odbioru słuchowego - selekcji istotnych informacji (11), nabywaniu wiedzy metakomunikacyjnej (1) oraz nadawaniu komunikatu zwrotnego (1), świadczącego o aktywnym słuchaniu odbiorcy w przestrzeni komunikacyjnej. Ponieważ propozycje autorów podręczników sprowadzają się przede wszystkim do wyposażenia uczniów w wiedzę i umiejętności warunkujące rozumienie tekstów literackich oraz filmów, praca nad percepcją słuchową służy realizacji tych celów, które są weryfikowane na egzaminach zewnętrznych. Większość poleceń opiera się na tekście literackim, więc umiejętność słuchowego odbioru komunikatów informacyjnych, perswazyjnych, publicystycznych itp. jest marginalizowana. Nasuwa się więc dość paradoksalny 
wniosek: mimo że badane zadania dydaktyczne mogą służyć kształceniu fundamentalnych sprawności percepcyjnych, nie przygotowują uczniów do kompetentnego odbioru komunikatów ustnych w sytuacjach pozaszkolnych.

Warto również zaznaczyć, że w badanych podręcznikach występują nieliczne ćwiczenia rozwijające słuchowy odbiór tekstu; w 66 zanalizowanych podręcznikach łącznie znajduje się jedynie 207 zadań doskonalących szczegółowe sprawności percepcyjne. Wynik ten wydaje się znikomy w porównaniu z ćwiczeniami służącymi rozwojowi pozostałych składowych kompetencji komunikacyjnej, szczególnie ze sprawnością czytania, którą częściej rozwija się w edukacji polonistycznej ${ }^{3}$. Na lekcjach języka polskiego doskonalenie sprawności odbioru wypowiedzi może być więc utożsamiane z pracą nad czytaniem ze zrozumieniem.

Na zakończenie niniejszego artykułu warto zaakcentować ogólną prawidłowość: w założeniu autorów podręczników w przyszłości wszyscy absolwenci szkół mają umieć mówić (do czego polska szkoła przygotowuje ), $^{\text {) }}$ więc ktoś ich będzie musiał słuchać; mówiący natomiast będą pragnęli być wysłuchiwani ${ }^{5}$, zatem sami muszą wykazywać chęci do odbioru komunikatów drugiej osoby. W innym przypadku w sytuacjach pozaszkolnych nie dojdzie do efektywnej komunikacji, która stanowi jeden z głównych celów współczesnego kształcenia językowego. Dlatego tak ważne jest rozwijanie wszystkich szczegółowych sprawności percepcyjnych, motywowanie do efektywnego słuchania w zróżnicowanych sytuacjach komunikacyjnych, wyposażanie uczniów w wiedzę metakomunikacyjną (o osobliwościach słuchania, obowiązkach odbiorcy w przestrzeni komunikacyjnej), innymi słowy - traktowanie sprawności słuchania na równi z pozostałymi umiejętnościami komunikacyjnymi, a nie jej marginalizowanie bądź też całkowite wykluczanie z edukacji polonistycznej.

\section{Wykaz cytowanych podręczników szkolnych}

GiS2: Czarniecka-Rodzik Zofia, 2012, Gramatyka i stylistyka 2. Podręcznik, Warszawa.

GiS3: Czarniecka-Rodzik Zofia, 2013, Gramatyka i stylistyka 3. Podręcznik, Warszawa.

MN3: Łuczak Agnieszka, Prylińska Ewa, Krzemieniewska-Kleban Kamila, 2011, Język polski. Między nami. Podręcznik dla klasy trzeciej gimnazjum, Gdańsk.

MN4: Łuczak Agnieszka, Murdzek Anna, 2012, Język polski. Między nami 4. Wersja dla nauczyciela, Gdańsk.

MN5: Łuczak Agnieszka, Murdzek Anna, 2013, Język polski. Między nami 5, Gdańsk.

\footnotetext{
Większość poleceń znajdujących się w badanych podręcznikach odnosiła się do odbioru tekstu pisanego. W analizowanych podręcznikach znajdują się liczne polecenia nakłaniające do tworzenia wypowiedzi 
MN6: Łuczak Agnieszka, Murdzek Anna, 2014, Język polski. Między nami 6, Gdańsk.

PS1.1: Chmiel Małgorzata, Kostrzewa Eliza, 2012, Ponad słowami. Podręcznik do języka polskiego dla liceum i technikum. Zakres podstawowy i rozszerzony. Klasa 1. Część 1, Warszawa.

PS2.1: Chmiel Małgorzata, Równy Anna, 2014, Ponad słowami. Podręcznik do języka polskiego dla liceum i technikum. Zakres podstawowy i rozszerzony. Klasa 2. Część 1, Warszawa.

PtD3: Kopciński Jacek, 2014, Przeszłość to dziś. Literatura, język, kultura. 3 klasa technikum i liceum, Warszawa.

SnCz2: Chmiel Małgorzata i in., 2009, Słowa na czasie. Podręcznik do kształcenia literackiego i kulturowego dla klasy drugiej gimnazjum, Straszyn k. Gdańska.

SnCz3.1: Herman Wilga, 2011, Słowa na czasie. Podręcznik do kształcenia językowego z ćwiczeniami dla klasy trzeciej gimnazjum, Straszyn k. Gdańska.

SnS4: Derlukiewicz Marlena, 2012, Słowa na start! Podręcznik do kształcenia literackiego i kulturowego dla klasy czwartej szkoły podstawowej, Warszawa.

SnS6: Wojciechowska Anna, Marcinkiewicz Agnieszka, 2014, Słowa na start! Podręcznik do kształcenia językowego dla klasy szóstej szkoły podstawowej.

Część II, Warszawa.

ŚwSiO2: Bobiński Witold, 2011, Świat w słowach i obrazach 2. Język polski. Podręcznik do gimnazjum, Warszawa.

TP6: Klimowicz Anna, 2014, Teraz polski! Podręcznik do kształcenia literackiego, kuturowego i językowego dla klasy szóstej szkoły podstawowej, Warszawa.

\section{Bibliografia:}

Adler Ronald Brian i in., 2006, Relacje interpersonalne. Proces porozumiewania się, Poznań.

Bartmiński Jerzy, Niebrzegowska-Bartmińska Stanisława, 2009, Tekstologia, Warszawa.

Brześkiewicz Zbigniew W., 1996, Supersłuchanie. Jak słuchać i być słuchanym, Warszawa.

Gronbeck Bruce E. i in., 2011, Zasady komunikacji werbalnej, Poznań.

Kurkowski Zdzisław Marek, 1997, Audiogenne uwarunkowania zaburzeń mowy, „Audiofonologia”, t. 10.

Lipińska Ewa, 1994, Słuchanie - sprawność zaniedbywana, „Przegląd Polonijny”, z. 4.

Morreale Sherwyn P., Spitzberg Brian H., Barge J. Kevin, 2007, Komunikacja między ludźmi. Motywacja, wiedza i umiejętności, Warszawa.

Nocoń Jolanta, 1997, Polecenia i pytania w podręcznikach do nauki o języku, Opole.

Patrzałek Tadeusz, 1997, Dobre słuchanie, „Polonistyka”, nr 6. 
Patrzałek Tadeusz, 1998, Dobre słuchanie, „Polonistyka”, nr 2.

Przybyla Olga, 2012, Dźwiękowe funkcje języka w kształceniu kompetencji językowej uczniów - problemy, uwagi i postulaty, w: Niesporek-

-Szamburska B. (red.), Wiedza o języku i kompetencje językowe uczniów, Katowice, s. 299-315.

Rocławski Bronisław, 1995, Słuch fonemowy i fonetyczny. Teoria i praktyka, Gdańsk.

Stróżyński Klemens, 2001, Słuchanie a komunikacja, „Polonistyka”, nr 7.

Uryga Zenon, 1996, Godziny polskiego. Z zagadnień kształcenia literackiego, Warszawa.

\section{O Autorce:}

Marta Urszula Chyb - mgr, doktorantka Wydziału Filologicznego Uniwersytetu Opolskiego. Interesuje się lingwodydaktyką, szczególnie uczeniem fonetyki i fonologii oraz doskonaleniem i diagnozą percepcji słuchowej na lekcjach języka polskiego. 